\title{
PENGEMBANGAN SOAL KEMAMPUAN PENALARAN MATEMATIS SISWA KELAS VII SMP
}

\author{
Asri Partika Dewi ${ }^{1}$, Mardiah Syofiana $^{2}$ \\ ${ }^{1,2}$ FKIP Universitas Muhamadiyah Bengkulu \\ asripartikadewi18@gmail.com \\ sofya203@gmail.com
}

\begin{abstract}
Abstrak
Penelitian ini bertujuan untuk mengembangkan soal penalaran matematis siswa yang valid dan praktis. Subjek dari peneilitian ini adalah siswa kelas VII SMP Negeri 57 Bengkulu Utara yang berjumlah 40 siswa. Penelitian ini menggunakan model Tessmer yang terdiri dari tahap preliminary, self evaluation, Expert review dan one-to-one, small group, dan field test. Pada penelitian pengembangan ini, hanya dibatasi pada tahap small group. Pada tahap preliminary dilakukan persiapan dan pendesainan soal. Tahap pengembangan terdiri dari self evaluation, Expert review dan one-to-one, small group. Soal yang telah didesain dan divalidasi secara valid, diuji cobakan kepada 15 orang siswa SMP Negeri 57 Bengkulu Utara dengan kemampuan heterogen. Data dikumpulkan melalui kartu validasi, wawancara, dan hasil mengerjakan soal pada tahap small group. Penelitian ini menghasilkan soal penalaran matematis siswa yang valid dan praktis.
\end{abstract}

Kata Kunci: Pengembangan soal, Kemampuan Penalaran Matematis

\begin{abstract}
This study aims to develop students' mathematical reasoning questions that are valid and practical. The subjects of this study were students of class VII SMP Negeri 57 Bengkulu Utara, totaling 40 students. This study uses the Tessmer model which consists of preliminary, self evaluation, expert review and one-to-one, small group, and field test. In this development research, it is only limited to the small group stage. In the preliminary stage, preparation and designing of questions are carried out. The development phase consists of self evaluation, Expert review and one-to-one, small group. The questions that were designed and validated validly were tested on 15 students of SMP Negeri 57 Bengkulu Utara with heterogeneous abilities. Data was collected through validation cards, interviews, and the results of working on the questions at the small group stage. This research produces valid and practice students' mathematical reasoning questions.
\end{abstract}

Keywords: Problem development, Mathematical Reasoning Ability

\section{PENDAHULUAN}

Dalam rumusan NCTM (National Council of Teacher of Mathematics) (2000) [6] ada lima kemampuan yang dikenal dengan kemampuan matematis (mathematical power) yaitu: (1) kemampuan pemecahan masalah, (2) kemampuan penalaran, (3) kemampuan berkomunikasi, (4) kemampuan membuat koneksi, (5) kemampuan representasi.

Berdasarkan kemampuan-kemampuan tersebut maka guru memiliki peran dan tanggung jawab yang besar dalam membekali siswa dengan kemampuankemampuan yang berguna untuk mencapai tujuan pembelajaran. Salah satu kemampuan yang dimaksud adalah kemampuan penalaran matematis.

Kemampuan penalaran sangat diperlukan dalam memahami suatu konsep materi pokok. Tanpa adanya kemampuan penalaran, maka siswa akan mengalami kesulitan dalam menyelesaikan suatu permasalahan dan itu dialami siswa karena 
terlalu menekankan proses pemahaman konsep pada hapalan saja tanpa menggunakan proses bernalar.

Gardner, et. al. [4] menyatakan bahwa kemampuan penalaran matematis adalah kemampuan dalam menganalisis, menggeneralisasi, mengintegrasi, memberikan alasan yang tepat, dan menyelesaikan masalah yang tidak rutin. Menurut NCTM [5] kemampuan penalaran matematis adalah suatu kemampuan yang mendukung seorang siswa untuk bisa mengembangkan dan mengekspresikan pengetahuan mereka tentang suatu fenomena baik konsep maupun prinsip matematika yang dihadapi. Sedangkan Shadiq [3] menyatakan bahwa kemampuan penalaran matematis adalah suatu kegiatan, suatu proses, atau suatu aktivitas untuk menarik kesimpulan atau membuat suatu pernyataan baru yang benar berdasar pada beberapa pernyataan yang kebenarannya telah dibuktikan sebelumnya.

Dari beberapa definisi kemampuan penalaran matematis di atas, dapat disimpulkan bahwa kemampuan penalaran matematis adalah salah satu proses berpikir yang dilakukan dengan cara menarik suatu kesimpulan dimana kesimpulan tersebut merupakan kesimpulan yang valid.

Secara garis besar penalaran matematis dapat digolongkan pada dua jenis, yaitu penalaran induktif dan penalaran deduktif. Penalaran induktif adalah penalaran yang berdasarkan sejumlah kasus atau contoh-contoh terbatas yang teramati. Penalaran deduktif adalah proses penalaran dari pengetahuan prinsip atau pengalaman umum yang menuntut kepada kesimpulan untuk sesuatu yang khusus [8].

Adapun indikator kemampuan penalaran matematis menurut Direktorat Jendral Pendidikan Sekolah Menengah melalui peraturan No. 506/C/Kep/PP/2004 antara lain:

a. Kemampuan menyajikan pernyataan matematika secara lisan, tertulis, gambar, dan diagram

b. Kemampuan mengajukan dugaan

c. Kemampuan melakukan manipulasi matematika

d. Kemampuan menyusun bukti, memberikan alasan atau bukti terhadap kebenaran solusi

e. Kemampuan menarik kesimpulan dari suatu pernyataan

f. Memeriksa kesahihan/kebenaran suatu argumen

g. Menemukan pola atas sifat dari gejala matematis untuk membuat generalisasi

Berdasarkan wawancara dengan guru di SMP Negeri 57 Bengkulu Utara, menurut informasi yang didapatkan bahwa selama ini dalam proses pembelajaran siswa umumnya mengerti ketika guru menjelaskan dan menyelesaikan materi kemudian memberikan beberapa contoh soal di kelas, akan tetapi ketika dihadapkan pada penyelesaian soal -soal yang sedikit berbeda dari contoh soal yang dijelaskan guru, mereka kesulitan melakukan manipulasi matematik, menarik kesimpulan, dan memberikan alasan atau bukti.

Mencermati hal tersebut, sehingga perlu dikembangkan soal-soal essay untuk kemampuan penalaran matematis. Untuk menghasilkan soal yang baik, harus dilakukan dalam prosedur pembuatan soal dan dilakukan dengan menganalisis soal. Soal yang terlalu sukar akan menyebabkan peserta didik akan putus asa dan tidak mempunyai semangat untuk mencoba lagi karena di luar jangkauannya. Sebaliknya, 
soal yang terlalu mudah tidak membuat siswa untuk mempertinggi usaha mengerjakannya.

Berdasarkan uraian tersebut dilakukan penelitian tentang "pengembangan soal essay pada materi Bentuk Aljabar untuk kemampuan penalaran matematis siswa kelas VII SMP".

\section{BAHAN DAN METODE}

Penelitian ini merupakan penelitian pengembangan atau development research tipe formative research (Tessmer dalam [9]). Dengan tujuan untuk menghasilkan soal-soal kemampuan penalaran matematis siswa. Penelitian ini dilaksanakan di kelas VII SMP Negeri 57 Bengkulu Utara.

Tahap pada model pengembangan Tessmer terdiri dari Preliminary, Self Evaluation, Expert Review, One-to-one, Small Group, dan Field Test.

Pada tahap Preliminary ini meliputi: persiapan, peneliti melakukan analisis kurikulum, siswa, materi, dan soal essay untuk kemampuan penalaran matematis siswa. Kemudian dilakukan desain soal-soal untuk kemampuan penalaran pada materi Bentuk Aljabar. Desain produk ini sebagai prototype.

Pada tahap Self Evaluation soal yang telah didesain dilihat dan dinilai sendiri oleh peneliti untuk penulisan dan bahasa sebelum divalidasi oleh pakar (Expert Reviews dan one-to-one).

Pada tahapExpert Review, desain soal yang dibuat atau yang disebut dengan prototype I berdasarkan self evaluation divalidasi oleh pakar (expert review). Pakar terdiri dari 2 dosen dan 1 guru matematika. Produk yang didesain divalidasi berdasarkan konten, konstruk, dan bahasa. Komentar dan saran dari validator ditulis pada lembar validasi sebagai bahan untuk merevisi. Produk yang telah divalidasi disebut Prototype II.

Pada tahap one-to-one peneliti meminta kepada 3 orang siswa yang terdiri dari siswa berkemampuan rendah, sedang, dan tinggi untuk memberikan saran dan komentar terhadap soal yang diberikan. Uji one-to-one digunakan untuk uji keterbacaan soal. Hasil komentar siswa digunakan untuk pertimbangan keterbacaan soal yang telah dibuat.

Hasil revisi pakar pada expert review dan one-to-one setelah divalidasi pada prototypeI dijadikan dasar untuk revisi desain prototypeI dan dinamakan prototype II. Divalidasi dan seterusnya sampai mendapatkan prototype yang valid menurut validator. Kemudian setelah soal valid, maka diuji cobakan pada small group yaitu 15 orang siswa SMP yang terdiri dari siswa berkemampuan heterogen. Tahap ini dilakukan untuk mengetahui kepraktisan dari soal-soal yang dibuat.

\section{HASIL DAN PEMBAHASAN \\ Tahap Preliminary}

Peneliti melakukan beberapa analisis, pertama analisis terhadap subjek penelitian yaitu siswa kelas VII SMP negeri 57 Bengkulu Utara, kedua analisis materi yaitu materi Bentuk Aljabar yang telah diberikan kepada siswa pada semester 1, ketiga analisis terhadap kurikulum yang digunakan di SMP Negeri 57 Bengkulu Utara yaitu Kurikulum 2013. Setelah dilakukan analisis, peneliti melakukan pendesainan soal kemampuan penalaran matematis. Desain produk ini disebut dengan prototype.

\section{Tahap Self Evaluation}


Prototype yang telah didesain berdasarkan materi dan indikator yang berjumlah 15 soal dinilai sendiri secara konten, konstruk, dan bahasa. Hal ini dilakukan sebelum divalidasi oleh pakar (ahli). Tahap ini menghasilkan soal prototype 1 .

Tahap Expert Review dan One-to-one

\section{$>$ Expert Review}

Expert Review melibatkan dua orang Dosen Prodi Pendidikan Matematika Universitas Muhammadiyah Bengkulu dan satu guru Matematika SMP Negeri 57 Bengkulu Utara. Setelah dilakukan ahli menganalisis soal-soal yang diberikan, ada beberapa komentar dan saran yang diberikan untuk dijadikan bahan pertimbangan dalam merevisi soal prototype 1. Menurut ahli ada beberapa soal yang harus direvisi. Berikut contoh revisi yang dilakukan berdasarkan para ahli.

Tabel 1. Contoh perubahan soal prototype 1 berdasarkan saran validator

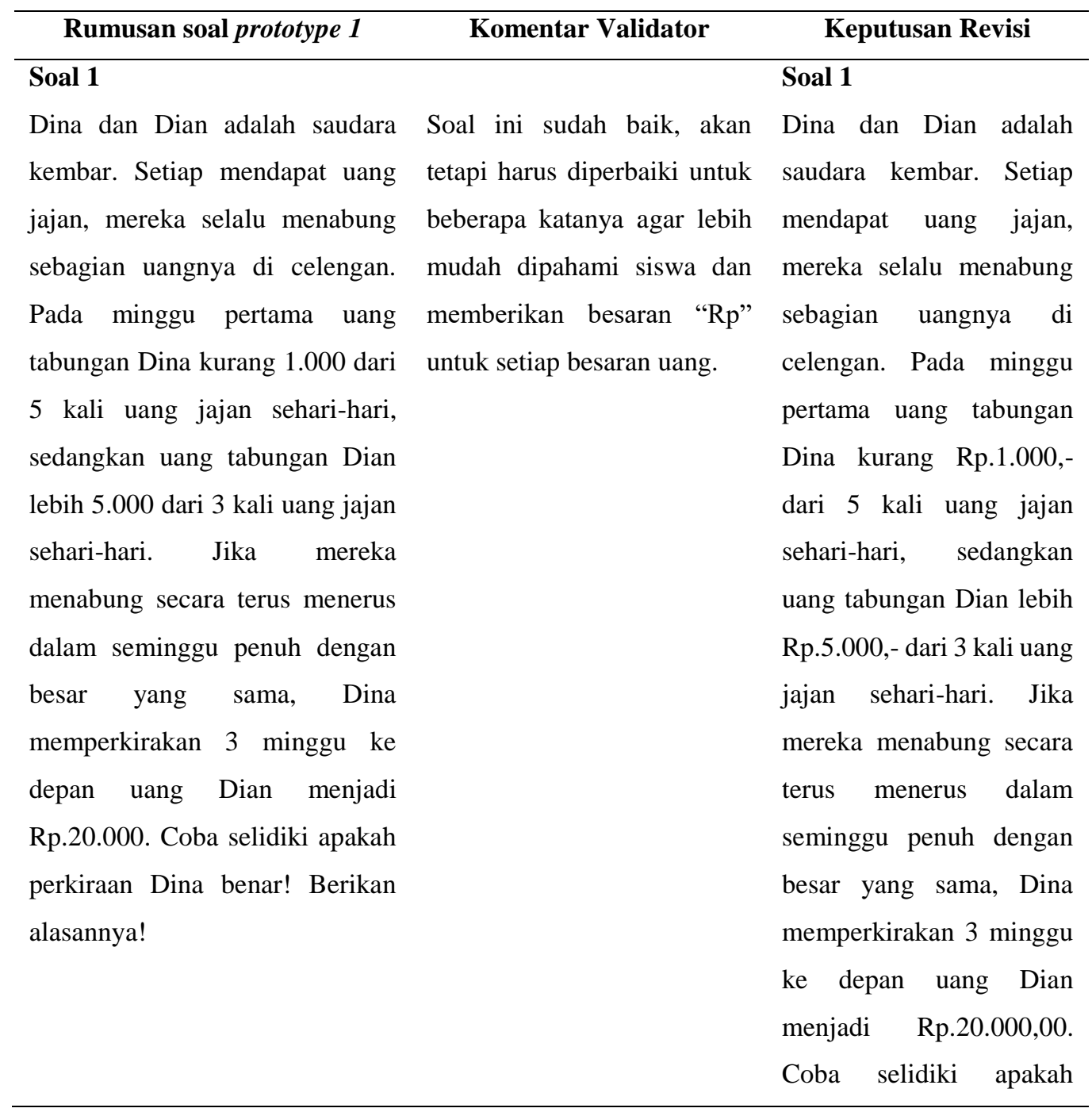




\section{perkiraan Dina benar! \\ Berikan alasannya!}

\section{Soal 2}

Pak Toni memiliki lahan berbentuk ersegi panjang seperti gambar di bawah in.

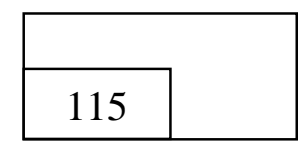

Lahan tersebut memiliki keliling $86 \mathrm{~m}$ dan panjang lebih 5 dari lebar lahan. Kemudian, sebagian dari lahan Pak Toni akan dibuat kolam ikan dengan ukuran yang telah ditentukan.
a. Buatlah bentuk aljabar dari permasalahan di atas!
b. Tentukanlah nilai panjang dan lebar lahan Pak Toni!
c. Hitunglah sisa luas lahan Pak Toni!

Soal sudah cukup baik, akan tetapi ada beberapa kata yang harus dirubah agar lebih efektif dan merubah letak gambar kolam.

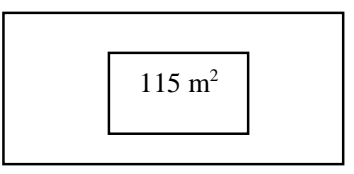

Pak Toni memiliki lahan berbentuk persegi panjang dengan keliling $86 \mathrm{~m}$ dan panjangnya lebih $5 \mathrm{~m}$ dari lebarnya. Kemudian, sebagian dari lahan tersebut akan dibuat kolam ikan dengan ukuran seperti pada gambar.
a. Tentukan nilai panjang dan lebar lahan Pak Toni!
b. Hitunglah sisa luas lahan Pak Toni!

\section{One-to-one}

Setelah tahap expert Review dilakukan tahap one-to-one. Soal prototype I diberikan kepada 3 orang siswa SMP kelas VII yang memiliki kemampuan heterogen dengan cara berhadapan satu lawan satu, yaitu penguji dan satu siswa. Pada tahap ini, siswa diminta membaca, memahami maksud dan tujuan, serta diwawancarai terhadap soal yang diberikan. Adapun hasil wawancara terhadap soal yang diuji cobakan, diperoleh kesimpulan secara garis besar siswa dapat memahami soal-soal yang diberikan. Hal ini menunjukkan bahwa keterbacaan soal pada tahap one-to-one sudah baik.

Setelah semua soal validasi direvisi, kemudian dilakukan lagi validasi kedua. Pada validasi kedua, semua soal dinyatakan sudah valid. Soal yang sudah valid ini dinamakan prototype II yang akan diujicobakan pada small group.

\section{Tahap Small Group}

Pada tahap small group, prototype II terdiri dari 15 soal yang merupakan hasil revisi pada tahap experts reviews dan one-to-one yang sudah valid diuji cobakan pada subjek penelitian small group yang berjumlah 15 orang siswa 
berkemampuan heterogen. Uji coba ini dilakukan untuk mengetahui kepraktisan dari soal yang sudah dibuat.

Uji coba soal dilakukan selama 1 hari dalam 75 menit. Subjek dibagi menjadi 3 kelompok dan setiap kelompok terdiri dari 5 orang siswa. Kelompok pertama mewakili siswa berkemampuan tinggi, kelompok kedua mewakili siswa berkemampuan sedang, dan kelompok ketiga mewakili siswa berkemampuan rendah. Setiap kelompok diberikan soal berbeda yang berjumlah 3 soal.

Prototype II terdiri dari 15 soal kemampuan penalaran matematis siswa kelas VII SMP pada materi bentuk aljabar. Berikut adalah contoh penyelesaian soal oleh siswa yang menunjukkan bahwa siswa tersebut telah memiliki kemampuan penalaran matematis.

\section{Soal 1}

Dina dan Dian adalah saudara kembar. Setiap mendapat uang jajan, mereka selalu menabung sebagian uangnya di celengan. Pada minggu pertama uang tabungan Dina kurang Rp.1.000,- dari 5 kali uang jajan sehari-hari, sedangkan uang tabungan Dian lebih Rp.5.000,- dari 3 kali uang jajan sehari-hari. Jika mereka menabung secara terus menerus dalam seminggu penuh dengan besar yang sama, Dina memperkirakan 3 minggu ke depan uang Dian menjadi Rp.20.000,-. Coba selidiki apakah perkiraan Dina benar! Berikan alasannya!

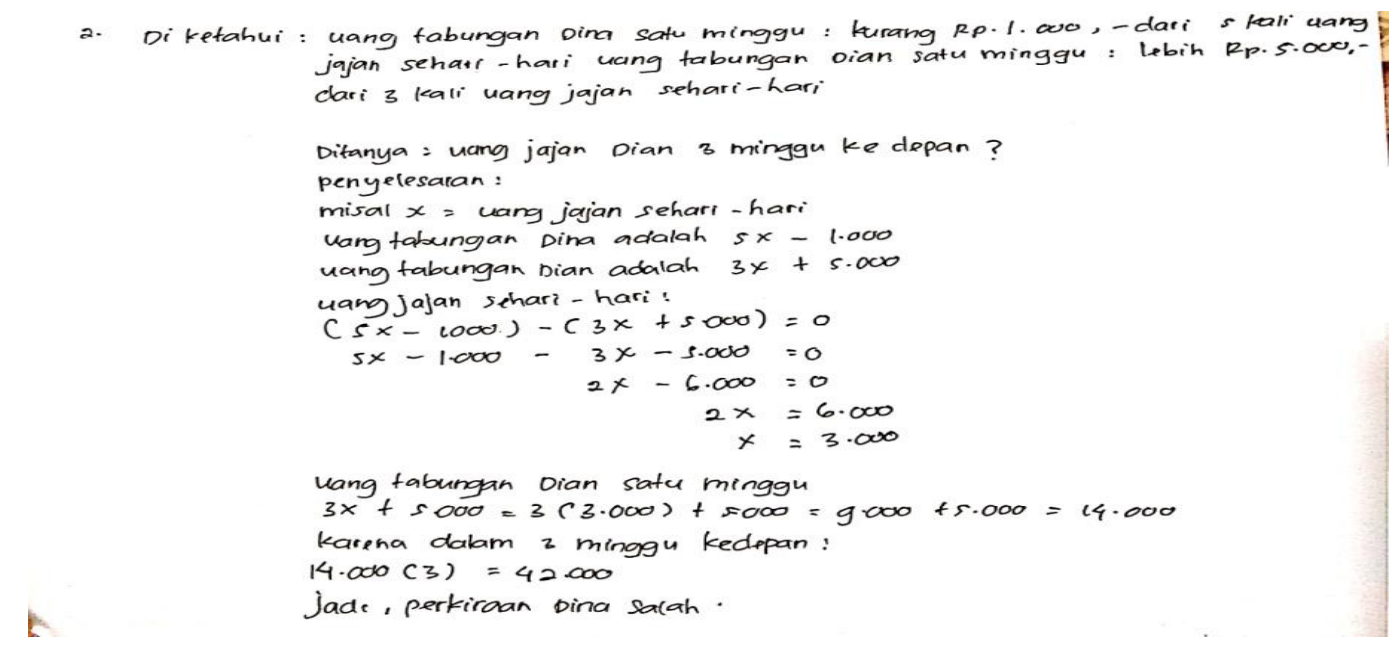

Gambar 1. Contoh penyelesaian siswa untuk soal 1

\section{Soal 2}

$115 \mathrm{~m}^{2}$

Pak Toni memiliki lahan berbentuk persegi panjang dengan keliling $86 \mathrm{~m}$ dan panjangnya lebih $5 \mathrm{~m}$ dari lebarnya. Kemudian, sebagian dari lahan tersebut akan dibuat kolam ikan dengan ukuran seperti pada gambar. 
a. Tentukan nilai panjang dan lebar lahan Pak Toni!

b. Hitunglah sisa luas lahan Pak Toni!

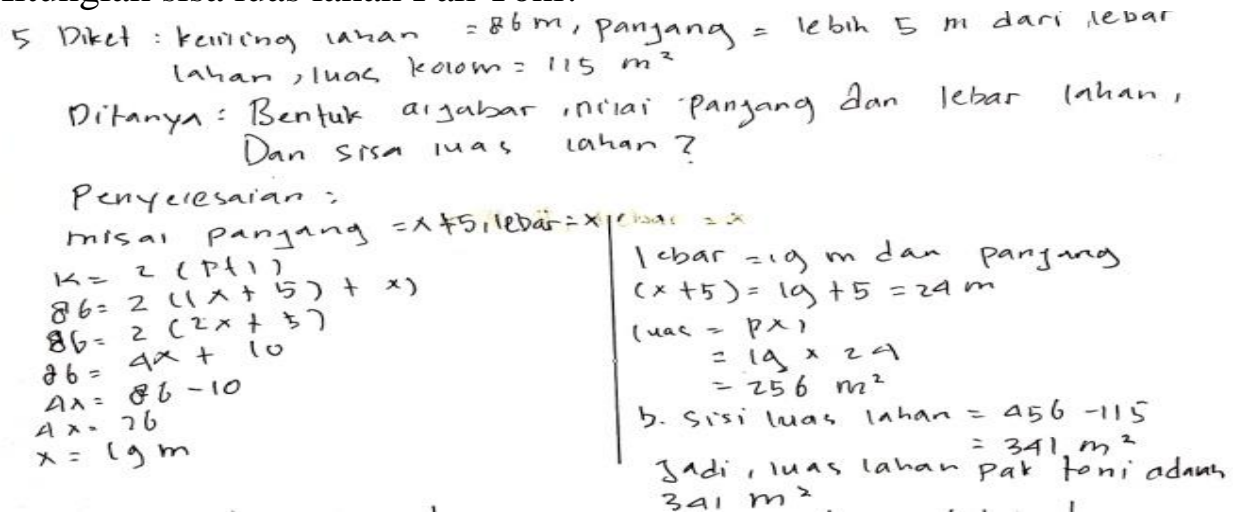

Gambar 2. Contoh penyelesaian siswa untuk soal 2

Dari jawaban kedua soal tersebut, secara umum siswa sudah dapat menyelesaikan dan memberikan ide yang merupakan hasil dari pemikirannya sendiri. Hal ini berarti dapat dikatakan bahwa siswa memiliki kemampuan penalaran matematis dan soal dapat dikatakan praktis karena bisa digunakan dengan baik oleh siswa.

\section{KESIMPULAN}

Penelitian ini telah menghasilkan 15 soal essay kemampuan penalaran matematis siswa kelas VII SMP pada materi bentuk aljabar yang valid dan praktis. Kevalidan soal terlihat dari proses pada tahap expert review atau proses dari validasi dan one-to-one. Kepraktisan soal terlihat dari proses small group. Karena keterbatasan peneliti, maka penelitian hanya dilakukan sampai tahap small group. Oleh karena itu, diharapkan untuk peneliti lain dapat melanjutkan penelitian sampai tahap field test.

\section{DAFTAR RUJUKAN}

[1] Abdul Basir, Mochamad. 2015. Kemampuan Penalaran Matematis Siswa Dalam Pemecahan Masalah Matematis Ditinjau Dari Gaya Kognitif." Jurnal Pendidikan Matematika FKIP Unissula, Vol. 3, No. 1. Diakses pada tanggal 21 November 2019 dari http://research.unissula.ac.id/file/publikasi/211312009/905jurnal edisi_3 no_1 th_2015.pd $\underline{\mathrm{f}}$

[2] Depdiknas. 2004. Peraturan tentang Penilaian Perkembangan Anak Didik SMP No. 506/C/Kep/PP/2004 Tanggal 11 November 2004. Jakarta: Ditjen Dikdasmen Depdiknas.

[3] Indah Lestari, dkk. 2015. Peningkatan Kemampuan Penalaran Matematis Siswa Menggunakan Pendekatan Pendidikan Matematika Realistik. Jurnal Inovasi Pendidikan Dasar, Vol 1. No 2. Diakses pada tanggal 01 Mei 2020 dari https://www.researchgate.net/publication/304022469_PENINGKATAN_KEMAMPUAN_ PENALARAN_MATEMATIS_SISWA_MENGGUNAKAN_PENDEKATAN_PENDIDI KAN_MAsTEMATIKA_REALISTIK

[4] Lestari dan Yudhanegara. 2015. Penelitian Pendidikan Matematika. Bandung: Refika Aditama

[5] NCTM. 2000. Principles and Standars for School Mathematics. Reston: The National Teachers of Council of Mathematics Inc. 
[6] Sri Sumartini, Tina. 2015. Peningkatan Kemampuan Penalaran Matematis Siswa Melalui Pembelajaran Berbasis Masalah. Jurnal Pendidikan matematika, Vol. 5, No. 1. Diambil pada $\begin{array}{lllll}\text { tanggal } & 27 & \text { Novemver } & 2019 & \text { dari }\end{array}$ https://journal.institutpendidikan.ac.id/index.php/mosharafa/article/view/mv4n1_1

[7] Sukiman. 2012. Pengembangan Media Pmbelajaran. Yogyakarta: Pustaka Insan Madani.

[8] Sumarmo, U. 2013. Kumpulan Makalah: Berpikir dan disposisi matematik serta pembelajarannya. Bandung: Jurusan Pendidikan Matematika, FPMIPA UPI.

[9] Zulkardi. 2006. Formative Evaluation: What, Why, When, and How. Diakses pada tanggal 13 Desember 2019 dari http://www.oocities.org/zulkardi/books.html 